\title{
Produksi dan Proporsi Potongan Karkas, dan Rib-eye Muscle Area Kambing Kejobong yang Diberi Pakan dengan Proporsi Hijauan dan Konsentrat Berbeda
}

\section{(Production and Portion Cuts of Carcass, and Rib Eye Muscle Area of Kejobong Goats Fed Different Proportion of Forage and Concentrate)}

\author{
Idealistina F, Dewi RK, Rasyid N, Dewani T, Arifin M, Adiwinarti R, Purbowati E, Mawati \\ S, Lestari CMS, Sutaryo
}

Fakultas Peternakan dan Pertanian, Universitas Diponegoro

faridaidealistina@gmail.com

\begin{abstract}
The aim of this study was to evaluate the effect of different proportions of forage and concentrate in diet on carcass productions, commercial cuts and edible portion of carcass in young and mature Kejobong goats. Sixteen heads of Kejobong goats were grouped into two different ages (young: 5 months old; initial body weight (BW) of $14.03 \mathrm{~kg} \pm 1.46 \mathrm{~kg}$ and mature: 9 months old; initial BW of $22.32 \pm 1.99 \mathrm{~kg}$ ). Each group was fed pelleted ration containing different proportions of forage and concentrate (T1 $=70: 30 \%$ and $\mathrm{T} 2=30: 70 \%$ ) about $4 \%$ of BW in dry matter (DM) basis. All goats were slaughtered after 4 months of feeding, then carcass, commercial cuts and edible portion were separated and weighed, also yield grade value and rib eye muscle area were weighed. Data were analyzed by nested design using F-test. The results showed that carcassses, commercial cuts and edible portion of mature goats were higher than those of young Kejobong, except for yield grade and rib-eye muscle area. Goats fed T2 produced higher $(\mathrm{P}<0.05)$ carcass production, commercial cuts (excluded neck), edible portion of carcass, and rib-eye muscle area than those fed T1. It can be concluded that $70 \%$ of concentrate for young and mature Kejobong goats can increase the carcass production, commercial cuts, edible portion of carcass, and rib-eye muscle area.
\end{abstract}

Key words: Kejobong goats, forage, concentrate, carcass, portion cut, rib-eye muscle area

\section{ABSTRAK}

Penelitian ini bertujuan untuk membandingkan produksi, potongan komersial dan edible portion karkas kambing Kejobong muda dan dewasa yang diberi pakan dengan proporsi hijauan dan konsentrat berbeda. Penelitian menggunakan 16 ekor kambing Kejobong jantan berbeda kelompok umur, yaitu muda (umur 5 bulan, BB 14,03 $\pm 1,46 \mathrm{~kg}$ ) dan dewasa (umur 9 bulan, BB 22,32 $\pm 1,99 \mathrm{~kg}$ ). Setiap kelompok umur yang berbeda, ternak diberi pakan pellet dengan proporsi hijauan dan konsentrat yang berbeda $(\mathrm{T} 1=70: 30 \%$ dan $\mathrm{T} 2=30: 70 \%)$ sebanyak 4\% BB. Setelah 4 bulan percobaan, kambing disembelih dan dipisahkan bagian karkas, potongan komersial dan edible portion karkas, dan juga yield grade dan eye muscle area nya. Data dianalisis menggunakan ANOVA pola tersarang dengan uji F. Hasil penelitian menunjukkan bahwa bobot karkas, potongan komersial dan edible portion karkas kambing Kejobong dewasa lebih tinggi $(\mathrm{P}<0,05)$ dari pada yang muda, akan tetapi nilai yield grade dan rib-eye muscle area nya relatif sama. Kambing perlakuan T2 menghasilkan karkas, potongan komersial (kecuali leher), edible portion karkas, dan rib-eye muscle area lebih besar $(\mathrm{P}<0,05)$ dari pada perlakuan T1. Disimpulkan bahwa pemberian konsentrat $70 \%$ ransum kepada 
kambing Kejobong muda maupun dewasa dapat meningkatkan produksi karkas, bobot potongan komersial karkas, edible portion karkas, dan rib-eye muscle area.

Kata kunci: Kambing kejobong, hijauan, konsentrat, karkas, proporsi potongan, rib-eye muscle area

\section{PENDAHULUAN}

Kambing Kejobong merupakan ternak ruminansia yang banyak digemari masyarakat karena memiliki potensi yang tinggi dalam hal produktivitas, namun demikian karena kebanyakan masyarakat peternak membudidayakan ternak secara ekstensif, maka potensi tersebut tidak dapat dimanfaatkan oleh peternak untuk meningkatkan keuntungan usahanya. Dalam sistem pemeliharaan ekstensif, ternak pada umumnya hanya diberi pakan hijauan sehingga membutuhkan waktu lebih lama untuk mencapai target bobot potong, sebab melalui pemberian pakan hijauan saja belum dapat terpenuhi kebutuhan nutrien pada ternak untuk memproduksi karkas secara maksimal.

Usaha untuk menghasilkan karkas kambing secara maksimal dapat dilakukan dengan cara menggunakan bakalan yang relatif muda dan perbaikan pakan dengan cara menambahkan suplemen protein (konsentrat sumber protein). Ternak muda sesuai dengan teori pertumbuhan memiliki potensi tumbuh yang sangat besar dibandingkan dengan ternak yang sudah mencapai umur dewasa (Soeparno 2015). Pertumbuhan kerangka yang meliputi panjang, tinggi dan lebar tubuh akan berpengaruh terhadap proporsi potongan komersial karkas. Potongan komersial karkas kambing terdiri atas 8 bagian yaitu paha (leg), punggung (loin), rusuk (rack), bahu (shoulder), leher (neck), lengan (shank), dada (breast) dan lipat paha (flank) (Sumardianto et al. 2013). Di sisi lain pemberian pakan yang berkualitas (kandungan protein yang mencukupi) dilaporkan oleh Soeparno (2015) dapat memperbaiki pertambahan bobot komponen karkas meliputi daging, tulang dan lemak. Solaiman et al. (2011) melaporkan bahwa peningkatan protein pakan dapat meningkatkan bobot badan pada ternak kambing yang juga diikuti dengan persentase karkas yang diperoleh, akan berpengaruh pula terhadap proporsi edible portion karkas yang berupa daging dan lemak. Perkiraan proporsi daging yang dihasilkan dapat dilihat dari yield grade dan rib-eye muscle area yang digambarkan dari potongan bagian loin.

Berdasarkan fenomena di atas, maka dilakukan penelitian peningkatan produksi karkas kambing Kejobong dengan umur bakalan yang berbeda dan suplementasi konsentrat 30\% dan 70\%. Diharapkan hasil penelitian ini dapat digunakan untuk menjelaskan pentingnya memperbaiki kualitas pakan (peningkatan kandungan protein) dalam upaya meningkatkan produksi karkas pada kambing Kejobong yang selama ini masih dibudidayakan secara ekstensif oleh peternak.

\section{MATERI DAN METODE}

\section{Materi penelitian}

Penelitian ini menggunakan kambing Kejobong jantan sebanyak 16 ekor terdiri dari 8 ekor umur muda ( \pm 5 bulan) dengan bobot badan awal rata-rata 14,03 $\pm 1,46 \mathrm{~kg}$ (CV $10,41 \%$ ) dan 8 ekor umur dewasa ( \pm 9 bulan) dengan bobot badan awal rata-rata 22,32 $\pm 1,99 \mathrm{~kg}$ (CV 8,92\%). Kambing tersebut diperoleh dari peternak di desa Kejobong, Kabupaten Purbalingga. Pakan yang digunakan yaitu rumput Kolonjono (Panicum muticum) dan konsentrat. Kandungan nutrisi rumput Kolonjono yaitu BK 88,63\%; Abu 
16,26\%; PK 6,24\%; LK 1,13\%; SK 26,50\%; BETN 49,87\% dan TDN 40,02\%. Konsentrat tersusun dari bahan pakan gaplek 6\%, bungkil kedelai $45 \%$, molases $6 \%$, dedak padi 42\% dan mineral mix 1\% dengan kandungan nutrisi BK 87,08\%; Abu 25,57\%; PK 20,34\%; LK 2,67\%; SK 21,87\%; BETN 41,02\% dan TDN 43,25\%.

\section{Metode penelitian}

Penelitian dilakukan menggunakan rancangan percobaan tersarang (nested design) dengan umur kambing sebagai faktor A dan ransum sebagai perlakuan faktor B sehingga faktor B tersarang dalam faktor A. Faktor A adalah umur muda dan umur dewasa, sedangkan faktor B adalah perlakuan pakan, yaitu:

T1 : 70\% rumput, 30\% konsentrat (BK= 86,75\%; $\mathrm{PK}=9,78 \%$; $\mathrm{TDN}=44,40 \%)$

T2 : 30\% rumput, 70\% konsentrat (BK= 86,68\%; PK= 14,52\%; TDN= 50,24\%)

Setiap perlakuan terdiri dari 8 ekor kambing Kejobong sebagai ulangan. Pakan diberikan sebanyak 4\% bobot badan dalam perhitungan bahan kering.

\section{Prosedur penelitian}

Penelitian dilaksanakan pada bulan September 2018-April 2019 di Fakultas Peternakan dan Pertanian Universitas Diponegoro, Semarang. Tahapan penelitian dimulai dari tahap persiapan, adaptasi, pendahuluan, perlakuan dan pengambilan data. Tahap persiapan dilakukan penyiapan kandang, peralatan, ternak dan pakan selama 10 hari. Tahap adaptasi (8 minggu) dilakukan dengan tujuan agar ternak terbiasa dengan lingkungan yang baru dan pakan yang berbeda dari pakan pada pemeliharaan di Purbalingga berupa hijauan. Tahap pendahuluan dilakukan dengan maksud menghilangkan pengaruh dari pakan sebelumnya, tahap ini dilakukan selama 1 minggu. Pada tahap perlakuan, ternak diberikan pakan sebanyak $4 \%$ bobot badan (secara restricted) yang diberikan sehari dua kali, yaitu pagi dan sore hari selama 16 minggu.

Setelah tahap perlakuan pakan selesai, kambing dipotong secara halal menurut syariat Islam pada bagian vena jugularis, oesophagus, arteri carotis, trachea dan kerongkongan. Selanjutnya dilakukan pengulitan, pengeluaran viscera dan penimbangan karkas. Pemotongan dilakukan selama 7 hari dan setiap harinya ada 2 kambing yang dipotong yaitu 1 kambing muda dan 1 kambing dewasa. Prosedur pemotongan dimulai dari pemuasaan kambing selama 12 jam. Kambing digantung pada kedua kaki bagian belakang pada persendian tendon achilles. Pemotongan kepala pada persendian atlantooccipital, sedangkan kaki pada persendian metacarpo-phalanges dan metatarsophalanges. Pengulitan dimulai dengan membuat irisan melingkar di bagian kaki belakang, dilanjutkan ke bagian perut, punggung dan dada sampai leher kemudian bagian kaki depan. Viscera dikeluarkan dengan membuka perut kemudian mengeluarkan organorgan viscera kecuali ginjal dan lemak ginjal. Testis, skrotum, penis serta ekor dipotong dari bagian karkas. Selanjutnya, karkas ditimbang untuk mengetahui bobot karkas panas, kemudian karkas dilayukan pada suhu $14^{\circ} \mathrm{C}$ selama 5 jam dan ditimbang lagi untuk mengetahui bobot karkas dingin. Karkas dibelah menjadi 2 bagian dan karkas bagian kanan dipotong menjadi 8 bagian potongan komersial seperti pada domba menurut Soeparno (2015), yaitu neck, shoulder, rack, shank, breast, loin, leg, dan flank (Gambar 1). Karkas diurai berdasarkan tulang, daging dan lemak. 


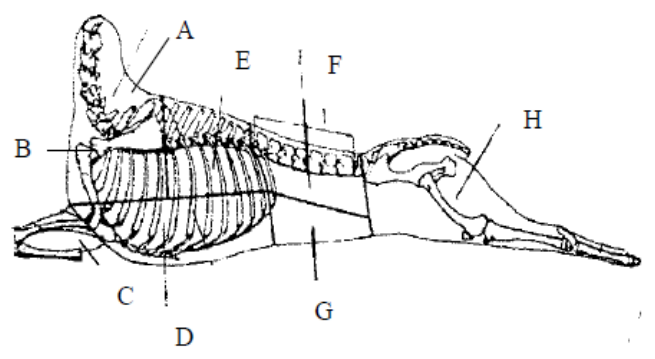

Keterangan :
A. Neck
B. Shoulder
C. Fore shank
D. Breast
E. Rack
F. Loin
G. Flank
H. Leg

Gambar 1. Potongan komersial karkas

Ketebalan lemak punggung diukur dengan menggunakan jangka sorong secara tegak lurus dengan permukaan lemak, pada posisi tiga perempat bagian sumbu panjang otot longissimus dorsi (Gambar 2). Yield grade dihitung menurut Judge et al. (1989) yaitu yield grade $=1,66+(6,66 \times$ ketebalan lemak $)+(0,25 \times$ persentase lemak ginjal dan pelvik) - (0,05 x kode skor konfirmasi paha). Rib-eye muscle area diukur antara rusuk ke-12 dan 13 menggunakan plastik grit (Gambar 2).
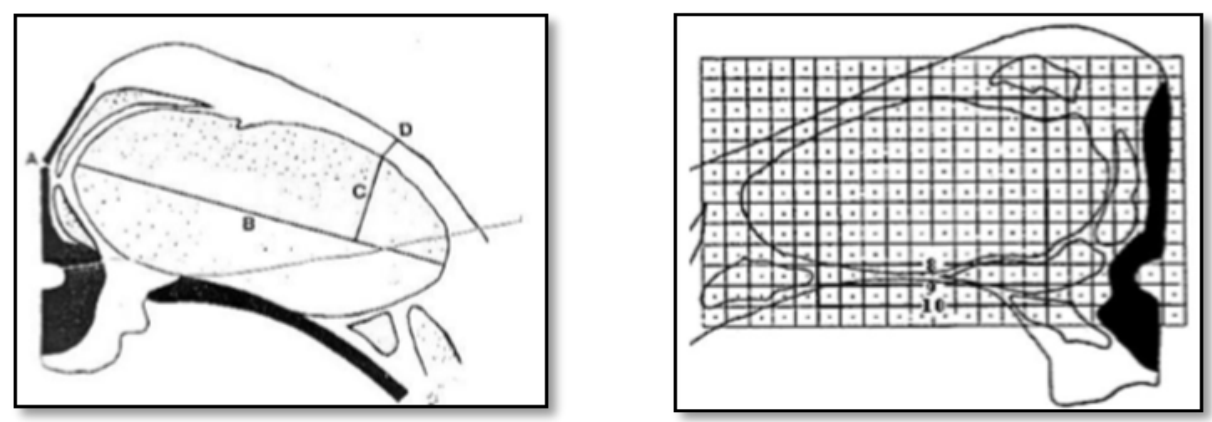

Gambar 2.Pengukuran ketebalan lemak pada titik D (kiri) dan perhitungan luas otot mata rusuk menggunakan plastik grit (kanan)

\section{Parameter penelitian}

Parameter yang diukur pada penelitian ini adalah bobot potong, bobot karkas, bobot potongan komersial, bobot edible portion karkas (daging dan lemak), yield grade dan ribeye muscle area. Bobot karkas adalah bobot badan ternak setelah dipotong dikurangi kepala, viscera, keempat kaki mulai dari tarsus dan carpus, kulit, ekor, darah kecuali ginjal dan lemak ginjal. Bobot karkas panas ditimbang sebelum dilakukan pelayuan, kemudian bobot karkas dingin ditimbang setelah pelayuan. Persentase karkas diperoleh dengan cara membandingkan bobot karkas dengan bobot potong dan dikalikan 100\%. Parameter pendukung yang dihitung adalah konsumsi pakan (BK, PK dan TDN).

\section{Analisis data}

Data yang diperoleh dianalisis menggunakan ANOVA (Analysis of Variance) nested design menurut Sudjana (1982) pada taraf signifikasi 5\%. 


\section{HASIL DAN PEMBAHASAN}

\section{Bobot potong, bobot karkas dan persentase karkas kambing}

Hasil penelitian menunjukkan bahwa peningkatan proporsi pemberian konsentrat dapat meningkatkan $(\mathrm{P}<0,05)$ bobot potong dan produksi karkas baik pada kambing Kejobong muda maupun dewasa (Tabel 1).

Tabel 1. Rata-rata bobot potong, bobot dan persentase karkas kambing Kejobong

\begin{tabular}{llccc}
\hline \hline \multirow{2}{*}{ Parameter } & \multirow{2}{*}{ Umur } & \multicolumn{2}{c}{ Pakan } & \multirow{2}{*}{ Rata-rata } \\
\cline { 3 - 4 } & & T1 & T2 & \\
\hline \multirow{2}{*}{ Bobot potong (g) } & Muda & $16.981,67^{\mathrm{a}}$ & $23.133,75^{\mathrm{b}}$ & $20.057,71^{\mathrm{x}}$ \\
& Dewasa & $25.511,25^{\mathrm{a}}$ & $30.668,75^{\mathrm{b}}$ & $28.090,00^{\mathrm{y}}$ \\
\multirow{2}{*}{ Karkas panas (g) } & Muda & $6.912,01^{\mathrm{a}}$ & $10.991,69^{\mathrm{b}}$ & $8.951,85^{\mathrm{x}}$ \\
& Dewasa & $12.035,47^{\mathrm{a}}$ & $14.914,90^{\mathrm{b}}$ & $13.475,19^{\mathrm{y}}$ \\
Karkas dingin utuh (g) & Muda & $6.639,58^{\mathrm{a}}$ & $10.802,50^{\mathrm{b}}$ & $8.721,04^{\mathrm{x}}$ \\
& Dewasa & $11.735,00^{\mathrm{a}}$ & $14.651,25^{\mathrm{b}}$ & $13.193,13^{\mathrm{y}}$ \\
Karkas panas (\%) & Muda & $44,69^{\mathrm{a}}$ & $50,58^{\mathrm{b}}$ & $47,63^{\mathrm{x}}$ \\
& Dewasa & $49,56^{\mathrm{a}}$ & $52,11^{\mathrm{b}}$ & $50,83^{\mathrm{y}}$ \\
Karkas dingin utuh (\%) & Muda & $43,11^{\mathrm{a}}$ & $49,71^{\mathrm{b}}$ & $46,41^{\mathrm{x}}$ \\
& Dewasa & $48,31^{\mathrm{a}}$ & $51,15^{\mathrm{b}}$ & $49,73^{\mathrm{y}}$ \\
\hline
\end{tabular}

Keterangan:

${ }^{\mathrm{a}, \mathrm{b}}$ Superskrip yang berbeda pada baris yang sama menunjukkan berbeda nyata $(\mathrm{P}<0,05)$.

${ }^{\mathrm{x}, \mathrm{y}}$ Superskrip yang berbeda pada kolom yang sama menunjukkan berbeda nyata $(\mathrm{P}<0,05)$.

Pemberian konsentrat 70\% menghasilkan produksi karkas yang lebih tinggi $(\mathrm{P}<0,05)$ dibandingkan konsentrat 30\%. Peningkatan produksi karkas tercatat baik pada bobot karkas panas maupun karkas dingin dan juga persentasenya (Tabel 1).

Bobot karkas kambing Kejobong dewasa pada penelitian ini lebih besar dibandingkan bobot karkas kambing Kejobong hasil penelitian Sumardianto et al. (2013). Hal tersebut dikarenakan pada penelitian Sumardianto et al. (2013) pakan yang diberikan hanya berupa hijauan sedangkan pada penelitian ini ada penambahan konsentrat dalam pakannya. Peningkatan pemberian konsentrat dalam pakan mampu meningkatkan produksi karkas baik pada kambing muda maupun dewasa dikarenakan kandungan nutrien (terutama protein) dalam konsentrat yang memiliki kualitas pakan yang lebih tinggi dan dapat berpengaruh terhadap pertumbuhan ternak, kualitas karkas dan produksi dagingnya. Menurut Hutama et al. (2014) pakan merupakan faktor penting yang perlu diperhatikan untuk memperoleh bobot potong yang optimal pada kambing seperti kandungan protein kasar (PK) yang melepaskan senyawa $\mathrm{N}$ dan total digestible nutrients (TDN) melepaskan senyawa C pada pakan yang dibutuhkan ternak untuk membentuk mikroba rumen, ketika mikroba rumen meningkat maka kecernaan pakan akan meningkat sehingga nutrisi yang dapat diserap ternak akan meningkat dan pada akhirnya bobot badan ternak ikut meningkat. Pemberian konsentrat 30\% pada kambing Kejobong muda dan dewasa hanya dimanfaatkan untuk memenuhi hidup pokok, sehingga saat kambing diberi konsentrat hingga 70\% masih mampu dimanfaatkan ternak untuk peningkatan 
produksi yang optimal. Peningkatan proporsi konsentrat dalam pakan hingga taraf 70\% masih mampu dimanfaatkan oleh kambing Kejobong muda maupun dewasa karena pada kambing muda nutrisi dimanfaatkan untuk laju pertumbuhan jaringan tulang dan otot agar semakin cepat, sedangkan pada kambing dewasa, nutrisi pada pakan dimanfaatkan untuk pembentukan jaringan lemak. Menurut Soeparno (2015) rasio protein dan energi akan memberikan pengaruh besar bagi ternak ruminansia muda dalam tahap pertumbuhan yang cepat. Hal tersebut juga didukung oleh pendapat Purbowati et al. (2008) bahwa pakan yang dikonsumsi oleh ternak akan dimanfaatkan untuk memenuhi kebutuhan hidup pokok, pertumbuhan, penggemukan dan tenaga.

\section{Potongan komersial karkas kambing}

Hasil penelitian bobot potongan komersial karkas kambing Kejobong muda dan dewasa dapat dilihat pada Tabel 2. Bobot potongan komersial karkas kambing dewasa lebih tinggi $(\mathrm{P}<0,05)$ dibanding kambing muda, karena bobot potong dan bobot karkas kambing dewasa lebih tinggi $(\mathrm{P}<0,05)$ dibanding kambing muda.

Tabel 2. Bobot potongan komersial karkas

\begin{tabular}{lcccc}
\hline \hline \multirow{2}{*}{ Parameter } & Umur & \multicolumn{2}{c}{ Pakan } & Rata-rata \\
\cline { 3 - 4 } & & T1 & T2 & \\
\cline { 3 - 4 } Neck & Muda & $570,24^{\mathrm{a}}$ & $622,66^{\mathrm{a}}$ & $596,45^{\mathrm{x}}$ \\
\multirow{2}{*}{ Shoulder } & Dewasa & $820,90^{\mathrm{a}}$ & $999,43^{\mathrm{a}}$ & $910,17^{\mathrm{y}}$ \\
& Muda & $1.395,51^{\mathrm{a}}$ & $2.434,32^{\mathrm{b}}$ & $1914,92^{\mathrm{x}}$ \\
Breast & Dewasa & $2.849,06^{\mathrm{a}}$ & $3.615,87^{\mathrm{b}}$ & $3.232,47^{\mathrm{y}}$ \\
& Muda & $579,50^{\mathrm{a}}$ & $1.073,26^{\mathrm{b}}$ & $826,38^{\mathrm{x}}$ \\
Rack & Dewasa & $1.071,27^{\mathrm{a}}$ & $1.421,54^{\mathrm{b}}$ & $1.246,41^{\mathrm{y}}$ \\
\multirow{2}{*}{ Flank } & Muda & $503,53^{\mathrm{a}}$ & $803,83^{\mathrm{b}}$ & $653,68^{\mathrm{x}}$ \\
& Dewasa & $908,80^{\mathrm{a}}$ & $1.138,91^{\mathrm{b}}$ & $1023,86^{\mathrm{y}}$ \\
Loin & Muda & $142,51^{\mathrm{a}}$ & $228,22^{\mathrm{b}}$ & $185,37^{\mathrm{x}}$ \\
& Dewasa & $235,89^{\mathrm{a}}$ & $330,84^{\mathrm{b}}$ & $283,37^{\mathrm{y}}$ \\
Leg & Muda & $543,48^{\mathrm{a}}$ & $976,69^{\mathrm{b}}$ & $760,09^{\mathrm{x}}$ \\
& Dewasa & $979,57^{\mathrm{a}}$ & $1.263,81^{\mathrm{b}}$ & $1.121,69^{\mathrm{y}}$ \\
Fore shank & Muda & $2.134,60^{\mathrm{a}}$ & $3.347,00^{\mathrm{b}}$ & $2.740,80^{\mathrm{x}}$ \\
& Dewasa & $3.621,61^{\mathrm{a}}$ & $4.436,96^{\mathrm{b}}$ & $4.029,29^{\mathrm{y}}$ \\
\hline
\end{tabular}

Keterangan :

${ }^{\mathrm{a}, \mathrm{b}}$ Superskrip yang berbeda pada baris yang sama menunjukkan berbeda nyata $(\mathrm{P}<0,05)$.

${ }^{\mathrm{x}, \mathrm{y}}$ Superskrip yang berbeda pada kolom yang sama menunjukkan berbeda nyata $(\mathrm{P}<0,05)$.

Potongan leg kambing dewasa memiliki bobot paling tinggi (4.029,29 g) dibanding potongan lainnya. Sesuai dengan pernyataan Sugana et al. (1983), bahwa leg merupakan 
bagian tubuh yang mengalami pertumbuhan awal karena digunakan sebagai alat gerak. Bobot potongan terbesar hingga terkecil yaitu leg, shoulder, loin, breast, fore shank, rack, neck dan flank. Soeparno (2015) menyatakan bahwa di awal pertumbuhan, laju pertumbuhan lambat, kemudian meningkat hingga pubertas dan mengalami penurunan setelah dewasa tubuh.

Potongan komersial karkas kambing Kejobong yang diberi pakan berbeda (T1 dan T2) menunjukkan hasil yang berbeda nyata $(\mathrm{P}<0,05)$, kecuali pada bagian neck tidak berbeda nyata $(\mathrm{P}>0,05)$. Konsumsi pakan T2 baik pada kambing muda (BK 0,83 kg; PK 0,12 kg; TDN 0,42 kg) maupun dewasa (BK 1,04 kg; PK 0,15 kg; TDN 0,52 kg) lebih tinggi dibanding konsumsi pakan T1 pada kambing muda (BK 0,68 kg; PK 0,07 kg; TDN 0,30 kg) dan dewasa (BK 0,96 kg; PK 0,09 kg; TDN 0,43 kg). Hal ini karena pakan T2 mengandung konsentrat lebih tinggi dan diduga lebih mudah dicerna, sehingga dapat dikonsumsi lebih banyak dibandingkan pakan T1 dengan proporsi konsentrat yang lebih sedikit. Konsumsi yang lebih tinggi dipengaruhi oleh laju pencernaan pakan, semakin cepat laju pencernaan pakan maka semakin banyak pakan yang dapat dikonsumsi (Sayekti et al. 2015). Kandungan nutrisi dan konsumsi pakan T2 yang lebih tinggi menghasilkan produksi karkas dan bobot potongan komersial yang tinggi. Hal ini sesuai dengan pendapat Soeparno (2015) bahwa bobot karkas dipengaruhi oleh bobot potong.

Bobot potongan komersial kambing Kejobong dewasa (1 tahun) yang diperoleh lebih besar dari penelitian Sari et al. (2016) yang menggunakan kambing Kacang jantan umur 1,5 tahun yang dipelihara secara tradisional menunjukkan hasil bobot potongan komersial yaitu neck (397 g), shoulder (1.087 g), rack (425 g), loin (495 g), breast (574 g), leg (1.767 g), flank (100 g) dan fore shank (744 g). Demikian pula dengan kambing Peranakan Etawah hasil penelitian Yosi (2014) menghasilkan bobot potongan komersial yang lebih rendah daripada penelitian ini yaitu neck (310 g), shoulder (900 g), rack (240 g), loin (230 g), breast (259 g), leg (1.030 g), dan fore shank (140 g).

\section{Edible portion karkas kambing}

Peningkatan proporsi konsentrat dalam pakan mampu meningkatkan $(\mathrm{P}<0,05)$ produksi edible portion karkas baik pada kambing Kejobong muda maupun dewasa. Produksi daging yang dihasilkan oleh kambing dewasa maupun kambing muda yang diberi pakan dengan konsentrat 70\% lebih tinggi dibandingkan kambing yang diberi pakan konsentrat 30\%. Hal tersebut dikarenakan produksi karkas yang dihasilkan tinggi sehingga menyebabkan produksi dagingnya juga tinggi. Akhmadi et al. (2005) menyatakan bahwa meningkatnya pemberian konsentrat dalam pakan, maka konsumsi PK akan meningkat pula dan memungkinkan bobot potong yang dihasilkan lebih tinggi sehingga daging yang diperoleh lebih banyak. Terdapat kecenderungan bahwa semakin tinggi bobot dan persentase karkas, maka bobot dan persentase edible portion karkas juga cenderung semakin tinggi.

Selain bobot daging, bobot lemak karkas kambing yang diberi pakan T2 juga lebih tinggi dibandingkan kambing yang diberi pakan T1 menyebabkan persentase lemak karkas yang dihasilkan juga tinggi. Hal tersebut karena terdapat hubungan yang erat antara bobot karkas dengan komponen-komponennya (Soeparno 2015). Persentase edible portion karkas yang tinggi disebabkan karena tingginya konsumsi pakan yang secara kuantitas dan kualitas lebih baik. Bobot dan persentase komponen karkas (daging dan lemak) kambing Kejobong dewasa pada penelitian ini (8594,60 g atau 64,99\%) lebih tinggi dibandingkan hasil penelitian Sumardianto et al. (2013) yaitu 6.405,58 g (62,33\%), namun demikian lebih rendah dari bobot edible portion karkas kambing Kacang yang 
diberi pakan total mixed ration yang mengandung bungkil kedelai yaitu sebesar 9,67 kg (80,94\%) karena ginjal (0,25 kg) termasuk dalam karkas (Adiwinarti et al. 2019).

Tabel 3. Bobot edible portion pada kambing kejobong muda dan dewasa

\begin{tabular}{lcccc}
\hline \hline \multirow{2}{*}{ Parameter } & Umur & \multicolumn{2}{c}{ Pakan } & \multirow{2}{*}{ Rata-rata } \\
\cline { 3 - 4 } & & $\mathrm{T} 1$ & $\mathrm{~T} 2$ & \\
\hline \multirow{2}{*}{ Daging (g) } & Muda & $4.020,78^{\mathrm{a}}$ & $6.894,95^{\mathrm{b}}$ & $5.457,86^{\mathrm{x}}$ \\
& Dewasa & $7.480,62^{\mathrm{a}}$ & $9.708,59^{\mathrm{b}}$ & $8.594,60^{\mathrm{y}}$ \\
Lemak (g) & Muda & $562,21^{\mathrm{a}}$ & $1.241,50^{\mathrm{b}}$ & $901,86^{\mathrm{x}}$ \\
& Dewasa & $1.204,02^{\mathrm{a}}$ & $1.607,90^{\mathrm{b}}$ & $1.405,96^{\mathrm{y}}$ \\
Daging (\%) & Muda & $60,41^{\mathrm{a}}$ & $63,78^{\mathrm{b}}$ & $62,09^{\mathrm{x}}$ \\
& Dewasa & $63,74^{\mathrm{a}}$ & $66,24^{\mathrm{b}}$ & $64,99^{\mathrm{y}}$ \\
Lemak (\%) & Muda & $8,84^{\mathrm{a}}$ & $11,51^{\mathrm{b}}$ & 10,18 \\
& Dewasa & $10,23^{\mathrm{a}}$ & $10,99^{\mathrm{b}}$ & 10,61 \\
\hline
\end{tabular}

Keterangan:

${ }^{\mathrm{a}, \mathrm{b}}$ Superskrip yang berbeda pada baris yang sama menunjukkan berbeda nyata $(\mathrm{P}<0,05)$

${ }^{\mathrm{x}, \mathrm{y}}$ Superskrip yang berbeda pada kolom yang sama menunjukkan berbeda nyata $(\mathrm{P}<0,05)$

\section{Yield grade}

Yield grade dan tebal lemak punggung pada perlakuan pakan tidak berbeda nyata $(\mathrm{P}>0,05)$ (Tabel 4) dengan rata-rata nilai yield grade 2 , karena tebal lemak punggungnya juga tidak berbeda nyata (rata-rata T1: 0,08 inci dan T2: 0,05 inci). Demikian juga dengan yield grade dan tebal lemak punggung pada umur yang berbeda tidak berbeda nyata $(\mathrm{P}>0,05)$ (Tabel 4).

Tabel 4. Yield grade, tebal lemak punggung dan rib-eye muscle area

\begin{tabular}{|c|c|c|c|c|}
\hline \multirow{2}{*}{ Parameter } & \multirow{2}{*}{ Umur } & \multicolumn{2}{|c|}{ Pakan } & \multirow{2}{*}{ Rata-rat } \\
\hline & & $\mathrm{T} 1$ & $\mathrm{~T} 2$ & \\
\hline \multirow{2}{*}{ Yield Grade } & Muda & 2 & 2 & 2 \\
\hline & Dewasa & 2 & 2 & 2 \\
\hline \multirow{2}{*}{$\begin{array}{l}\text { Tebal Lemak Punggung } \\
\text { (inci) }\end{array}$} & Muda & 0,10 & 0,06 & 0,08 \\
\hline & Dewasa & 0,07 & 0,05 & 0,06 \\
\hline \multirow{2}{*}{ Rib-eye Muscle Area $\left(\mathrm{cm}^{2}\right)$} & Muda & $9,92^{\mathrm{a}}$ & $14,25^{b}$ & 12,08 \\
\hline & Dewasa & $12,75^{\mathrm{a}}$ & $14,81^{\mathrm{b}}$ & 13,78 \\
\hline
\end{tabular}

Keterangan :

${ }^{\mathrm{a}, \mathrm{b}}$ Superskrip yang berbeda pada baris yang sama menunjukkan berbeda nyata $(\mathrm{P}<0,05)$.

${ }^{\mathrm{x}, \mathrm{y}}$ Superskrip yang berbeda pada kolom yang sama menunjukkan berbeda nyata $(\mathrm{P}<0,05)$.

Nilai rib-eye muscle area pada perlakuan pakan T2 lebih besar $(\mathrm{P}<0,05)$ dibanding T1 (Tabel 4), baik pada umur muda maupun dewasa. Hal ini menunjukkan bahwa kambing yang diberi konsentrat 70\% menghasilkan rib-eye muscle area yang lebih besar 
$(\mathrm{P}<0,05)$ dibanding kambing yang diberi pakan konsentrat 30\%. Rib-eye muscle area hasil penelitian ini lebih besar dibandingkan dengan rib-eye muscle area pada kambing Kacang hasil penelitian Purbowati et al. (2011) yaitu 7,6 $\mathrm{cm}^{2}$. Perbedaan tersebut karena faktor bangsa, pakan, bobot karkas dan bobot potong. Semakin luas permukaan rib-eye muscle area, semakin banyak pula daging pada potongan loin. Namun demikian, rib-eye muscle area kambing Kejobong tidak berbeda nyata $(\mathrm{P}>0,05)$ pada umur yang berbeda (Tabel 4), karena rib-eye muscle area sudah mencapai ukuran maksimal dan keduanya masuk pada fase laju pertumbuhan diperlambat (muda: 9 bulan, dewasa: 12 bulan).

\section{KESIMPULAN}

Kesimpulan hasil penelitian ini adalah produksi karkas, potongan komersial, edible portion karkas, dan rib-eye muscle area pada kambing Kejobong dapat diperbaiki dengan cara penambahan pakan konsentrat sampai level 70\% baik pada kambing muda maupun dewasa.

\section{DAFTAR PUSTAKA}

Adiwinarti R, Budisatria IGS, Kustantinah, Rusman, Indarto E, Purnomoadi A. 2019. Edible portion of carcass and offal of Indonesian yearling Kacang buck fed ruminally undegradable protein. In: The UGM Annual Scientific Conference Life Sciences 2016. KnE Life Science. p. 271-280. doi: 10.18502/kls.v4i11.3873.

Akhmadi D, Purbowati E, Adiwinarti R. 2005. Persentase edible portion domba yang diberi ampas tahu kering dengan aras yang berbeda. J Indones Trop Anim Agric. 30:248-253.

Hutama YG, Lestari CMS, Purbowati E. 2014. Produksi karkas dan non karkas kambing Kacang jantan yang diberi pakan dengan level protein dan energi berbeda. J Anim Agricul. 3:17-23.

Judge MD, Aberle ED, Forrest JC, Hedrick HB, Merkel RA. 1989. Principles of meat science. Kendall/Hunt Publishing Company, Dubuque.

Purbowati E, Sutrisno CI, Baliarti E, Budhi SPS, Lestariana W. 2008. Pemanfaatan energi pakan komplit berjadar protein-energi berbeda pada domba lokal jantan yang digemukkan secara feedlot. J Indones Trop Anim Agric. 33:59-65.

Purbowati E, Prasojo TA, Kusuma A, Aqsha GE, Albab MU. 2011. Yield grade dan rib-eye areakambing Kacang, Peranakan Etawa dan Kejobong jantan pada umur satu tahun. Prosiding Seminar Nasional Peternakan Berkelanjutan III "Road to Green Farming". Bandung (Indonesia): Fakultas Peternakan, Universitas Padjadjaran. hlm. 79-84.

Sari RT, Purnomoadi A, Adiwinarti R. 2016. Potongan komersial dan komponen karkas kambing Kacang Jantan umur 1,5 tahun dengan pemeliharaan tradisional (studi kasus di Kecamatan Wirosari Kabupaten Grobogan). J Anim Agric. 5:11-16.

Sayekti I, Purbowati E, Rianto E. 2015. Pemanfaatan protein pakan pada domba lokal jantan yang mendapat pakan pada siang dan malam hari. J Animal Agriculture. 13:22-27.

Solaiman S, Min BR, Gurung N, Behrend J, Taha E. 2011. Assessing feed intake, growth performance, organ growth, and carcass characteristic of purebred Boer and Kiko male kids fed high concentrate diet. Small Rumin Res. 98:98-101.

Soeparno. 2015. Ilmu dan teknologi daging. Edisi keenam. Yogyakarta (Indonesia): Gadjah Mada University Press.

Sudjana. 1982. Metode statistika. Bandung (Indonesia): Tarsito. 
Sugana N, Duldjaman M, Natasasmita A, Saparto. 1983. Paha dan lemusir domba lokal Priangan berdasarkan jenis kelamin dan pengelompokan bobot potong. Pertemuan Ilmiah Penelitian Ruminansia Kecil. Bogor (Indonesia): Pusat Penelitian dan Pengembangan Peternakan. hlm. 278-281.

Sumardianto TAP, Purbowati E, Masykuri. 2013. Karakteristik karkas kambing Kacang, kambing Peranakan Ettawa dan kambing Kejobong jantan pada umur satu tahun. J Anim Agric. 1:175-182.

Yosi RC. 2014. Karakteristik karkas dan non karkas kambing kacang dan kambing peranakan etawah pada bobot potong $17 \mathrm{~kg}$ [Skripsi]. [Bogor (Indonesia)]: Institut Pertanian Bogor. 